\title{
Potentiation of a novel palladium (II) complex lethality with bee venom on the human T-cell acute lymphoblastic leukemia cell line (MOLT-4)
}

\author{
Zahra Safaeinejad, Mohammad Nabiuni ${ }^{*}$ and Zahra Nazari
}

\begin{abstract}
Background: Although honeybee venom (BV) has been reported to induce apoptosis in different types of cancerous cells, its synergistic effects with customary anti-cancer drugs remain largely unknown. In the present study, we evaluated the cytotoxic effect of BV alone (as a natural product) and the synergistic cytological effects of this component in combination with [Pd (bpy) (Pi-Pydtc)] $\mathrm{NO}_{3}$ - a novel palladium complex on human T-cell lymphoblastic leukemia cells. To investigate the cytotoxic effect of the BV alone and in combination with palladium complex on MOLT-4 cells MTT assay was performed. In order to determine the apoptotic effects of BV separately and in combination with Pd (II) complex on these cells and its ability to induce apoptosis, morphological examination, flowcytometric analysis and caspase-3 colorimetric assay were done.

Results: We found that BV induced morphological changes, namely nuclear shrinkage, and inhibited MOLT-4 cell proliferation; both effects were dose- and time-dependent. Flow cytometry by Annexin- $V$ antibody demonstrated that BV induced apoptosis in MOLT-4 cells. Furthermore, BV induced apoptosis independently of caspase-3 in these cells. In addition, we proved a clear synergistic effect of BV on [Pd (bpy) (Pi-Pydtc)] $\mathrm{NO}_{3}$. The apoptotic pathway activated by BV in combination with Pd complex was caspase-3-dependent.
\end{abstract}

Conclusions: These observations provide an explanation for the anti-proliferative properties of BV, and suggest that this agent may be useful for treating lymphoblastic leukemia alone or in combination with chemotherapy drugs pending further investigations on animal models as preclinical tests.

Keywords: Apoptosis, Bee venoms, Cytotoxicity, MOLT-4 cell line, Pd (II) complex

\section{Background}

Bee venom is a natural substance that contains only $0.1 \mu \mathrm{g}$ of dry venom [1]. The dry venom has a very complex mixture of such active peptides as melittin, apamin and adolapine, enzymes including hyaluronidase and phospholipase A2, biologically active amines such as histamine and epinephrine as well as non-peptide components with numerous medicinal properties [2]. Melittin, a hemolytic and strong cardiotoxic peptide, is the major active ingredient of BV. This main constituent of bee venom has been reported to induce apoptosis, and to produce anti-tumor effects [3,4]. Melittin, which makes up $50-60 \%$ of the dry venom, is a low-molecular-weight

\footnotetext{
* Correspondence: nabiuni@khu.ac.ir

Department of Cell and Molecular Biology, Faculty of Biological Sciences, Kharazmi University, Tehran, Iran
}

protein $(2846.46 \mathrm{Da})$, which is composed of 26 amino acids. It is found as a tetramer in the poison sac of the bee, but when influencing a cell, it acts as a monomer [5].

BV has been used as a traditional medicine to treat various diseases such as arthritis, rheumatism, back pain and skin diseases [2]. Besides, recent studies have reported that BV causes growth arrest and exerts cytotoxic effects on various types of cancerous cells [6-11]. The cytotoxic effects mediated through the activation of PLA2 by melittin have been suggested to be the critical mechanism for the anti-cancer activity of BV [12].

It is well documented that induction of apoptosis is the most effective strategy by which anti-cancer agents target cancer cells [13]. Chemotherapy agents can induce apoptosis signaling through two major pathways. One is the mitochondrial (intrinsic) pathway and the other one is the death receptor (extrinsic) pathway. Cascading 
intrinsic pathway activation of certain molecules finally provokes activation of downstream caspase-3, which is one of the key agents of apoptosis. Activated caspase-3 cleaves a wide array of substrates, such as poly(ADP-ribose) polymerase (PARP), a DNA repair enzyme, and inevitably leads to cell death $[14,15]$.

Cisplatin (cis-diammine dichloroplatinum II) is one of the most remarkable drugs which is used separately or in combination with other chemotherapy agents to treat different types of tumors [16,17]. Despite the success of cisplatin and platinum-based drugs, they have presented serious clinical side effects $[18,19]$. Therefore, much effort has been focused on identifying novel anti-tumor agents and examining new approaches to increase their damage to tumor cells at a lower concentration than conventional chemotherapy drugs [20].

The significant similarities between the coordination chemistry of palladium (II) and platinum (II) compounds have generated lines of research on Pd (II) complexes as anti-tumor components [21]. Recently we stated at the FAOBMB conference that [Pd (bpy) (Pi-Pydtc) $\mathrm{NO}_{3}$, as a novel palladium complex designed and synthesized by our research group, exerts clear anti-tumor effects on human lymphoblastic leukemia MOLT-4 cells [22].

In the present study, we first examined the cytotoxic effect of BV on the MOLT-4 cancerous cell line, then the synergistic effects of BV and the novel Pd (II), [Pd (bpy)(Pi-Pydtc)]NO3, on these cells. This investigation employed the following techniques: MTT assay, morphological analysis, flow-cytometry assay and the caspase 3 activity assay.

\section{Methods}

\section{Bee venom collection and novel Pd (II) complex preparation}

Venom from the Iranian honey bee (Apis mellifera) was prepared by placing bees on a 6-mm wire grid, which was electrically pulsed. The bees then produced venom that dropped onto a glass slide, from which it was collected and freeze-dried according to the method of Lariviere and Melzack [23], whereas the novel complex of the Pd (II) was designed and synthesized by our research group [24].

\section{Cell culture}

The human T-cell acute lymphoblastic leukemia MOLT4 cells were purchased from the Pasteur Institute (Tehran, Iran). Cells were maintained in RPMI-1640 medium (Gibco, UK) and supplemented with 10\% fetal bovine serum (Gibco, UK), penicillin at 100 units $/ \mathrm{mL}$, and streptomycin at $100 \mu \mathrm{g} / \mathrm{mL}$, in a humidified incubator filled with $5 \% \mathrm{CO}_{2}$ at $37^{\circ} \mathrm{C}$. The medium was replaced every 48 hours.

\section{MTT cytotoxicity assay}

In order to determine the cytotoxic effects of BV separately and in combination with Pd (II) complex on the MOLT-4 cells, cell viability was tested by MTT (3[4, 5-dimethylthiozol-2-yl]-2,5-diphenyl tetrazolium bromide) assay. The cells were first seeded into 24-well culture plates (Nunc, Denmark) at a density of $1.0 \times 10^{5}$ cells $/ \mathrm{mL}$ and subsequently incubated in a humidified $5 \%$ $\mathrm{CO}_{2}$ environment for one hour. The cells were then treated with $\mathrm{BV}$ at $1,3,6$ and $8 \mu \mathrm{g} / \mathrm{mL}$ for 24 and 48 hours, the concentrations chosen as a result of precipitation of the BV in the medium. Non-treated cells were used as controls.

MTT (100 $\mu \mathrm{L}$ of $5 \mathrm{mg} / \mathrm{mL}$ ) (Sigma, USA) was added to each well and incubated at $37^{\circ} \mathrm{C}$ for four hours. The dark blue crystals were dissolved by adding $1000 \mu \mathrm{L}$ of $0.04 \mathrm{M} \mathrm{HCl} /$ isopropanol. After an overnight incubation in darkness, optical density (O.D.) was read at a wavelength of $570 \mathrm{~nm}$ using a spectrophotometer. The O.D. values of the experimental groups were divided by those of the untreated control group, and the results were presented as the percentage of cell viability.

By calculating the minimum BV dosage that killed MOLT-4 cells, we exposed cells to the lowest lethal dosages of BV and Pd (II) complex simultaneously [1 $\mu \mathrm{g} / \mathrm{mL}$ BV/0.85 $\mu \mathrm{M}$ Pd (II) complex, $3 \mu \mathrm{g} / \mathrm{mL} \mathrm{BV} / 0.85 \mu \mathrm{M}$ Pd (II) complex and $6.3 \mu \mathrm{g} / \mathrm{mL}$ BV/0.85 $\mu \mathrm{M}$ Pd (II) complex] for 24 hours. Cell survival was determined as described above.

\section{Morphological analysis}

To monitor the effect of BV alone and in combination with Pd (II) complex on MOLT-4 cells, the cells were treated with BV and BV/Pd (II) complex, then morphologically analyzed under an inverted microscope to see whether these components were able to induce condensation of their nuclei.

\section{Apoptosis analysis by flow cytometry}

In this study, apoptosis was measured by means of a flow cytometry assay. Cells were treated with BV and BV/Pd (II) complex for 24 hours. Then, these cells were harvested and washed with PBS. After washing, the cells were resuspended in $100 \mu \mathrm{L}$ Annexin-V (Abcam, UK) (diluted 1:100 in blocking buffer BSA/PBS 1\%) and samples were incubated overnight at $4^{\circ} \mathrm{C}$. Next, the cells were washed with PBS and centrifuged $(2000 \mathrm{rpm} / 10 \mathrm{mi}-$ nutes); the supernatant was aspirated and cells were incubated in the dark with $50 \mu \mathrm{L}$ fluorescein-labeled goat anti-rabbit secondary antibody (diluted 1:100 in blocking buffer BSA/PBS $1 \%$ ) for 45 minutes at $37^{\circ} \mathrm{C}$. Finally, $300 \mu \mathrm{L}$ of $1 \%$ formaldehyde was added to each tube and data were analyzed by flow cytometry using a 
FACSCalibur and the software Cell Quest (Becton Dickinson, USA).

\section{Caspase activity assay}

Caspase activity was determined by colorimetric assay using a caspase-3 activation kit (Abcam, UK) according to the manufacturer's protocol. Briefly, cells were first treated with different concentrations of BV (3.15, 6.3 and $12.6 \mu \mathrm{g} / \mathrm{mL}$ ) and BV/Pd (II) complex $[0.5 \mu \mathrm{g} / \mathrm{mL}$ BV/0.425 $\mu \mathrm{M}$ Pd (II) complex and $1 \mu \mathrm{g} / \mathrm{mL}$ BV/0.85 $\mu \mathrm{M}$ Pd (II) complex], and then lysed in lysis buffer. The supernatant was collected and incubated with the supplied reaction buffer, containing dithiothreitol and substrates, at $37^{\circ} \mathrm{C}$ for two hours. The reaction was measured by changes in the absorbance at $405 \mathrm{~nm}$ using a microplate reader. The level of caspase enzymatic activity in the cell lysate was proportional to the optical absorbance, which was read with an ELISA reader (Biotech, USA).

\section{Statistical analyses}

Statistical differences were determined by one-way analysis of variance (ANOVA), with the results expressed as mean \pm standard error of the mean (S.E.M.) for three independent experiments $(n=3)$. Differences were considered significant for $\mathrm{p}>0.01$.

\section{Results}

\section{Cell viability assay}

In order to determine the optimal dose and time of cytotoxic effect of BV alone and in combination with this novel Pd (II) complex on MOLT-4 cells, an MTT assay was performed. The cells were treated with BV at various concentrations for 24 and 48 hours and with BV/Pd (II) complex for 24 hours. The respective viabilities of cells treated with BV at concentrations of $1,3,6$ and $8 \mu \mathrm{g} / \mathrm{mL}$ for 24 hours were $87.5 \pm 0.500,81.5 \pm 2.500$,
$54 \pm 2.828$ and $44.5 \pm 3.5$ in relation to the control value. The viabilities of cells treated with BV at the concentrations of 1,3 and $6 \mu \mathrm{g} / \mathrm{mL}$ for 48 hours were $38 \pm 4,28 \pm$ 2.309 and $25.6 \pm 2.728$ relative to the control value, respectively (Figure 1A).

The viabilities of cells treated with BV/Pd (II) complex at concentration of $1 \mu \mathrm{g} / \mathrm{mL} \quad B V / 0.85 \mu \mathrm{M}$ Pd (II) complex, $3 \mu \mathrm{g} / \mathrm{mL} \mathrm{BV} / 0.85 \mu \mathrm{M}$ Pd (II) complex and $6.3 \mu \mathrm{g} / \mathrm{mL}$ BV/0.85 $\mu \mathrm{M}$ Pd (II) complex for 24 hours were $49.33 \pm 1.435,35 \pm 0.5774,27.33 \pm 1.453$ in relation to the control value, in that order (Figure 1B).

These results reveal that the cytotoxic effect of BV alone and in combination with Pd (II) complex on MOLT-4 cells is dose- and time dependent (Figure 1A and $\mathrm{B})$. Based on these data, the respective $50 \%$ cytotoxic concentrations $\left(\mathrm{Cc}_{50}\right)$ of the $\mathrm{BV}$ after 24 and 48 hours of incubation were 6.3 and $0.6 \mu \mathrm{g} / \mathrm{mL}$. The $\mathrm{Cc}_{50}$ value of $\mathrm{BV}$ in combination with $\mathrm{Pd}$ (II) complex was $1 \mu \mathrm{g} / \mathrm{mL}$ BV/0.85 $\mu \mathrm{M}$ Pd (II) complex after 24 hours of incubation. The optimal dose and treatment time of $\mathrm{BV}$ alone and in combination with Pd (II) complex to be used in subsequent experiments were set according to $\mathrm{Cc}_{50}$ values of these components at 24 hours.

\section{Cellular morphological changes with BV and BV/Pd (II) complex}

To examine the effects of BV and BV/Pd(II) complex on MOLT-4 cell morphology, cells were treated with $\mathrm{BV}$ and BV/Pd (II) complex and examined by phasecontrast microscopy. As shown in Figure 2, cells treated with BV (Figure 2B) or with BV/Pd complex (Figure 2C) displayed greater nuclear condensation than the control group (Figure 2A). This morphological characteristic suggests that BV alone or in combination with Pd (II) complex induces apoptotic cell death in MOLT-4 cells.
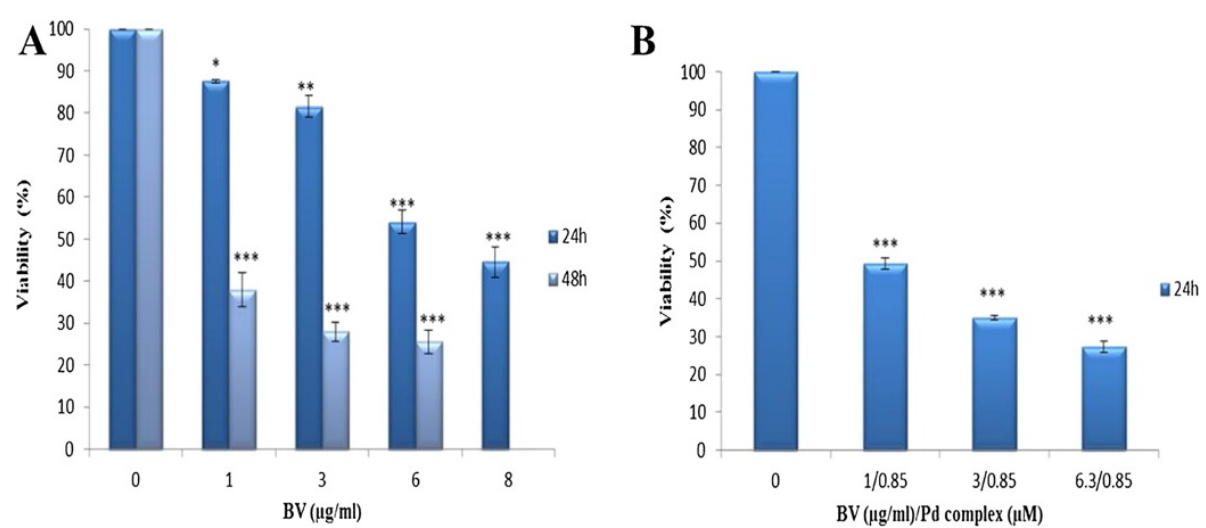

Figure 1 Growth inhibition and cell death were determined via MTT assay. (A) Dose- and time-dependent effect of BV and (B) dose effect of BV/Pd (II) complex on viability of MOLT-4 cells. Results are presented as mean \pm S.E.M. $n=3$; ** $p>0.01$ and ${ }^{* * *} p>0.001$ significantly different from the control. 

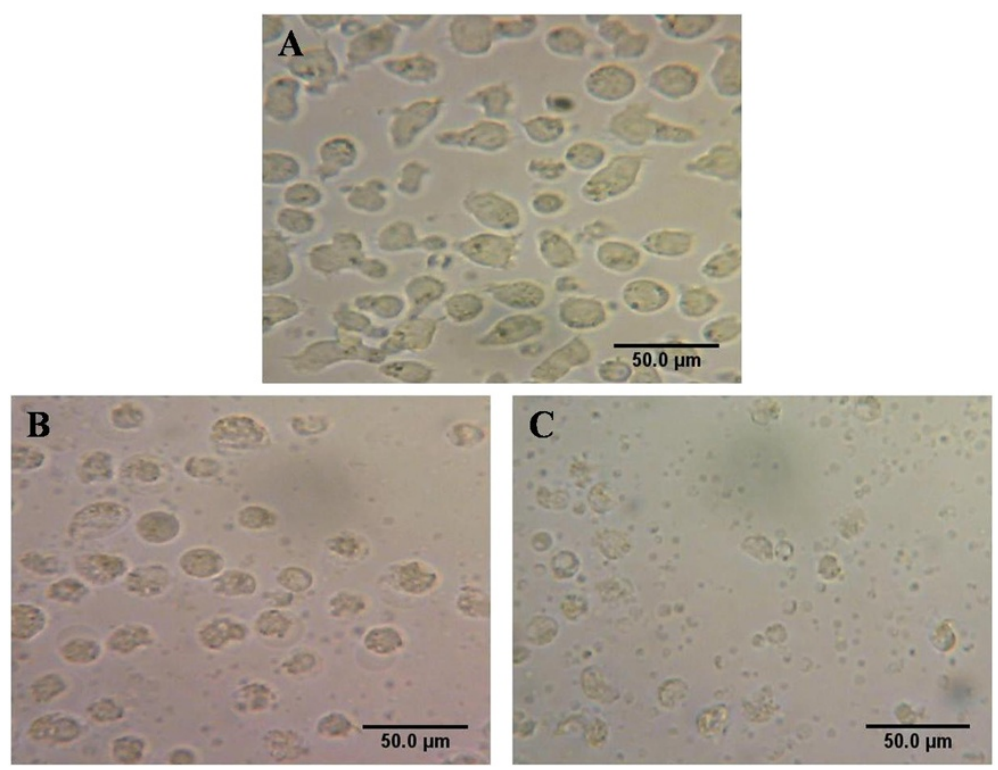

Figure 2 Effect of BV and BV/Pd (II) complex on the morphology of MOLT-4 cells. Photomicrographs from inverted microscope. Condensed nuclei obviously indicate apoptosis. (A) Controls, (B) cell treated with BV, (C) cells treated with BV/Pd (II) complex.

\section{Flow cytometry}

To prove that $\mathrm{BV}$ and $\mathrm{BV} / \mathrm{Pd}(\mathrm{II})$ complex induce apoptosis in MOLT-4 cells, a flow cytometric analysis with Annexin-V was performed (Figure 3). The results confirmed that the cells exposed to BV alone or in combination with Pd (II) complex for 24 hours enter the early stage of apoptosis. Apoptosis was induced in $32.30 \%$ of the cells exposed simultaneously to the $\mathrm{Cc}_{50}$ value of these two components.

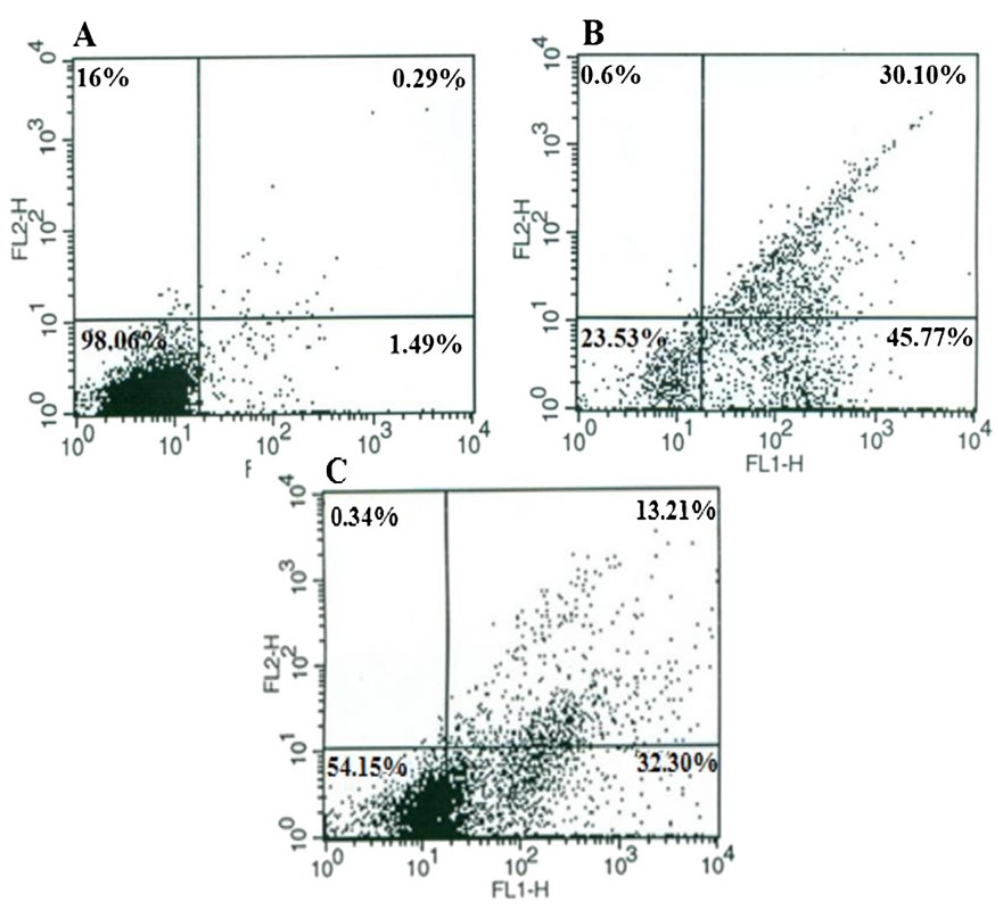

Figure 3 Characterization of BV and BV/Pd (II) complex-induced apoptosis in MOLT-4 cells by flow cytometry. Cells were cultured (A) without any component (control), (B) with BV and (C) with BV/Pd (II) complex for 24 hours. Note that $32.30 \%$ of the cells exposed to $\mathrm{C}_{50}$ value of these two components simultaneously [1 $\mathrm{gg} / \mathrm{mL}$ BV/0.85 $\mu \mathrm{M}$ Pd (II) complex] enter early apoptosis stage. 


\section{Caspase-3 enzyme activity}

Caspase-3 enzyme activity was measured by a colorimetric assay. The enzyme activity assay revealed that caspase 3 was not affected by BV. The optical density of the samples exposed simultaneously to BV and Pd (II) complex increased from 0.075 to 0.1033 and from 0.075 to 0.14266 at $1 / 2 \mathrm{Cc}_{50}[0.5 \mu \mathrm{g} / \mathrm{mL} \mathrm{BV} / 0.425 \mu \mathrm{M} \mathrm{Pd}$ (II) complex] and $\mathrm{Cc}_{50}[1 \mu \mathrm{g} / \mathrm{mL} \mathrm{BV} / 0.85 \mu \mathrm{M} \mathrm{Pd}(\mathrm{II})$ complex], respectively (Figure 4).

\section{Discussion and conclusions}

Although it has been previously reported that bee venom can inhibit human cancer cell growth through induction of apoptosis in many cancer cell lines such as prostate cancer, breast cancer and melanoma, there is no finding of the induction of apoptosis in human $\mathrm{T}$ cell acute lymphoblastic leukemia cells by BV [6-8]. Based on our knowledge, the present study is the first report about examination of the synergistic effect of BV with a palladium metal-based component.

Analysis of cytotoxicity by MTT assay proved that BV is both time- and dose-dependent in its cytotoxic effects, given that the $\mathrm{Cc}_{50}$ values of this component were 6.3 and $0.6 \mu \mathrm{g} / \mathrm{mL}$ after 24 and 48 hours, respectively. Due to the inconsistency in the MTT assay data - as a result of precipitation of the BV at high concentrations after 24 and 48 hours, and at low concentrations after 48 hours - only the concentrations less than $10 \mu \mathrm{g} / \mathrm{mL}$ were applied in these experiments. At these concentrations the findings were acceptable, except at $8 \mu \mathrm{g} / \mathrm{mL}$ after 48 hours, which again resulted in precipitation of the $\mathrm{BV}$.

The lethal dosage of BV in MOLT-4 cells is about $6.3 \mu \mathrm{g} / \mathrm{mL}$, which is lower than that for lung cancer cells reported by Jang et al. [9] $(10 \mu \mathrm{g} / \mathrm{mL})$, but exceeds that of leukemia U937 cells (about $2 \mu \mathrm{g} / \mathrm{mL}$ after 48 hours), as well as human melanoma A2058 cells $(2 \mu \mathrm{g} / \mathrm{mL}$ after one hour) $[8,10]$. However, BV required different durations to induce cell death in these distinct types of cancerous cells. Such differences may be due to the biological and genetic variations between the investigated cell types. Morphological analysis and the results of flow cytometry indicated that the type of cell death induced by $\mathrm{BV}$ is apoptosis.

The present data have also revealed that expression of caspase-3 protein in MOLT-4 cells exposed to BV is down-regulated. Ip et al. [11], when examining the effect of honey bee venom on human cervical epidermoid carcinoma Ca Ski cells, observed that bee venom induced cell cycle arrest and apoptosis in these cells in caspasedependent and caspase-independent pathways [11]. Tu et al. [8] also indicated that bee venom induces calciumdependent but caspase-independent apoptotic cell death in human melanoma A2058 cells.

On the contrary, BV induced apoptosis in human leukemia U937 cells through down-regulation of the ERK and Akt signaling pathway, with Bcl-2 and caspase3 as the key regulators [10]. A large amount of evidence indicates that apoptosis-induced factors (AIF) and endonuclease G (EndoG) act as major apoptosis agents in the caspase-independent cell death pathway [25-28].

In addition to the abovementioned effects, we proved that lethal effects of Pd complex were potentiated by adding a non-lethal dose of the bee venom. On the other hand, BV exerts a strong synergistic effect on the Pd (II) complex. Our preliminary data, which were presented at the FAOBMB Conference, indicated that $1.7 \mu \mathrm{M}[\mathrm{Pd}$ (bpy)(Pi-Pydtc) $\mathrm{NO}_{3}$ produces a cytotoxic effect on the MOLT-4 cells. It was also demonstrated that the lethal dose of this newly synthesized palladium complex can induce apoptosis in these cells [22].
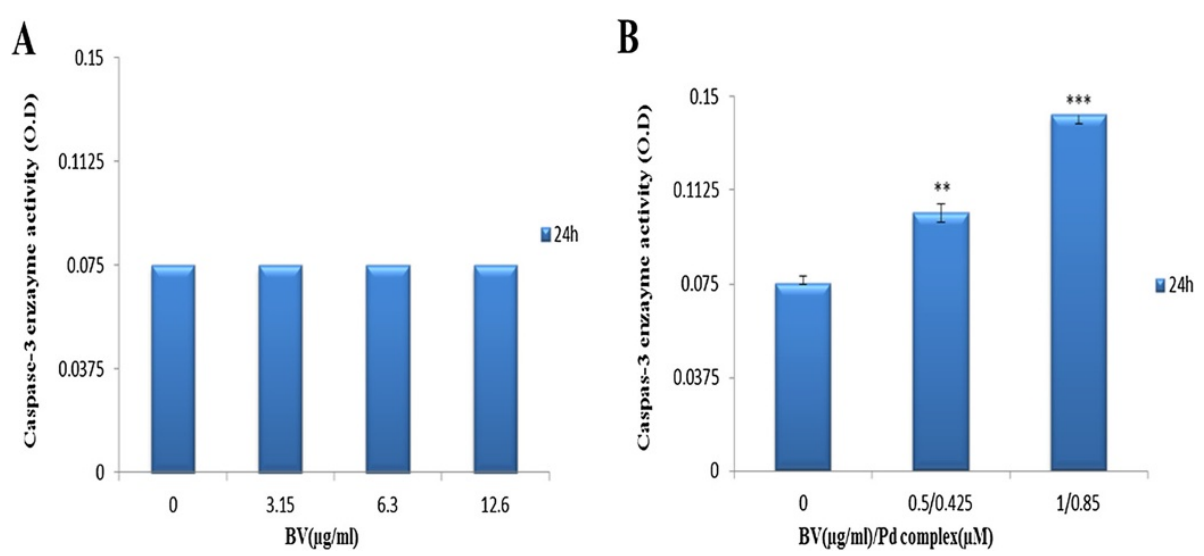

Figure 4 Results of caspase-3 enzyme activity assay. Cells treated (A) with BV and (B) with BV/Pd (II) complex. The optical density was measured at $405 \mathrm{~nm}$. The OD values were not altered by increasing BV, while the OD values rose following a dose increase from $1 / 2 \mathrm{Cc}_{50} \mathrm{BV} / \mathrm{Pd}$

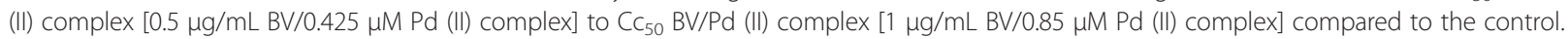
Data represent mean \pm SEM of three different experiments. $n=3$; *** $p>0.001$ significantly different from the control. 
In the present study, we demonstrated that when BV and palladium (II) complex were consumed simultaneously, the combination of $1 \mu \mathrm{g} / \mathrm{mL}$ BV with $0.85 \mu \mathrm{M}$ Pd (II) complex induces MOLT-4-cell apoptosis in a caspase-3-dependent manner. Orsolic [29], while investigating cytotoxic effects of bee venom applied alone or in combination with the DNA-damaging drug bleomycin on HeLa and V79 cells, found that bleomycin caused a dose-dependent decrease in cell survival. When used with a non-lethal dose of the BV, its lethal effect was potentiated. The author inferred that BV, by preventing repair of damaged DNA, increases bleomycin lethality and inhibited recovery from bleomycin-induced damage [29].

Because DNA is the main target of palladium metalbased complexes, we may conclude that $\mathrm{BV}$ is able to potentiate the lethality effect of $[\mathrm{Pd}$ (bpy)(Pi-Pydtc) $] \mathrm{NO}_{3}$ in this manner. In summary, the results of the present study suggest that the BV induces apoptosis in human lymphoblastic leukemia cells and, if further studies on animal models confirm these results, that bee venom may be used with customary chemotherapy agents to improve their cytotoxic effects.

\section{Ethics committee approval}

The present study was approved by the Ethics Committee of the Faculty of Biological Sciences at Kharazmi University.

\section{Competing interests}

The authors declare that there are no competing interests.

\section{Authors' contributions}

All authors contributed equally to this work. All authors read and approved the final manuscript.

\section{Acknowledgments}

The authors are grateful to the head of Biology Department and Cell and Developmental Biology Research Laboratory as well as Animal House Unit of the Faculty of Biological Sciences, at Kharazmi University for the financial support and to Dr. H. Mansouri Tourshizi for providing the novel palladium complex to our research lab. We also thank Dr. Imani for collaborating in the $\mathrm{BV}$ collection.

Received: 20 March 2013 Accepted: 3 September 2013

Published: 3 October 2013

\section{References}

1. Dotimas EM, Hider RC: Honeybee venom. Bee World 1987, 68(2):51-70.

2. Son DJ, Lee JW, Lee YH, Song HS, Lee CK, Hong JT: Therapeutic application of anti-arthritis, pain-releasing, and anti-cancer effects of bee venom and its constituent compounds. Pharmacol Ther 2007 115(2):246-270

3. Vento R, D'Alessandro N, Giuliano M, Lauricella M, Carabillò M, Tesoriere G: Induction of apoptosis by arachidonic acid in human retinoblastoma Y79 cells: involvement of oxidative stress. Exp Eye Res 2000, 70(4):503-517

4. Winder D, Gunzburg WH, Erfle V, Salmons B: Expression of antimicrobial peptides has an antitumour effect in human cells. Biochem Biophys Res Commun 1998, 242(3):608-612

5. Kaiser T, Brennecke SP, Moses EK: Methylenetetrahydrofolate reductase polymorphisms are not a risk factor for preeclampsia/eclampsia in Australian women. Gynecol Obstet Invest 2000, 50(2):100-102.

6. Park MH, Choi MS, Kwak DH, Oh KW, Yoon do Y, Han SB, Song HS, Song MJ, Hong JT: Anti-cancer effect of bee venom in prostate cancer cells through activation of caspase pathway via inactivation of NF-kB. Prostate 2011, 71(8):801-812.

7. Ip SW, Liao SS, Lin SY, Lin JP, Yang JS, Lin ML, Chen GW, Lu HF, Lin MW, Han SM, Chung JG: The role of mitochondria in bee venom-induced apoptosis in human breast cancer MCF7 cells. In Vivo 2008, 22(2):237-245

8. Tu WC, Wu CC, Hsieh HL, Chen CY, Hsu SL: Honeybee venom induces calcium-dependent but caspase-independent apoptotic cell death in human melanoma A2058 cells. Toxicon 2008, 52(2):318-329.

9. Jang MH, Shin MC, Lim S, Han SM, Park HJ, Shin I, Lee JS, Kim KA, Kim EH, Kim CJ: Bee venom induces apoptosis and inhibits expression of cyclooxygenase-2 mRNA in human lung cancer cell line NCl-H1299. J Pharmacol Sci 2003, 91(2):95-104.

10. Moon DO, Park SY, Heo MS, Kim KC, Park C, Ko WS, Choi YH, Kim GY: Key regulators in bee venom-induced apoptosis are $\mathrm{BCl}-2$ and caspase- 3 in human leukemic U937 cells through downregulation of ERK and Akt. Int Immunopharmacol 2006, 6(12):1796-1807.

11. Ip SW, Wei HC, Lin JP, Kuo HM, Liu KC, Hsu SC, Yang JS, Chiu TH, Han SM, Chung JC, Mei-Dueyang: Bee venom induced cell cycle arrest and apoptosis in human cervical epidermoid carcinoma Ca Ski cells. Anticancer Res 2008, 28(2A):833-842.

12. Orsolic N: Bee venom in cancer therapy. Cancer Metastasis Rev 2012, 31(1-2):173-194.

13. Kaufmann SH, Earnshaw WC: Induction of apoptosis by cancer chemotherapy. Exp Cell Res 2000, 256(1):42-49.

14. Hengartner MO: The biochemistry of apoptosis. Nature 2000, 407(6805):770-776

15. Cohen GM: Caspases: the executioners of apoptosis. Biochem J 1997 326(Pt 1):1-16.

16. Sun RW, Ma DL, Wong EL, Che CM: Some uses of transition metal complexes as anti-cancer and anti-HIV agents. Dalton Trans 2007, 21(43):4884-4892.

17. Cooley ME, Davis LE, DeStefano M, Abrahm J: Cisplatin: a clinical review. Part I - Current uses of cisplatin and administration guidelines. Cancer Nurs 1994, 17(3):173-184.

18. Martínez A, Lorenzo J, Prieto MJ, Font-Bardia M, Solans X, Avilés FX, Moreno $V$ : Influence of the position of substituents in the cytotoxic activity of trans platinum complexes with hydroxymethylpyridines. Bioorg Med Chem 2007, 15(2):969-979.

19. Ronconi L, Giovagnini L, Marzano C, Bettio F, Graziani R, Pilloni G, Fregona D: Gold dithiocarbamate derivatives as potential antineoplastic agents: design, spectroscopic properties, and in vitro antitumor activity. Inorg Chem 2005, 44(6):1867-1881.

20. Akdi K, Vilaplana RA, Kamah S, Navarro JA, Salas JM, González-Vílchez F: Study of the biological effects and DNA damage exerted by a new dipalladium-Hmtpo complex on human cancer cells. J Inorg Biochem 2002, 90(1-2):51-60.

21. Mansoori-Torshizi H, Islami-Moghaddam M, Saboury AA: A microcalorimetry and spectroscopy study on the interaction of BSA with 2, 2'bipyridine octylglycinato Palladium (II) Nitrate. Acta Biochim Biophys Sin (Shangai) 2003, 35(10):886-890.

22. Nabiuni M, Divsalar A, Mansouri-Torshizi H, Safayinejad Z: Cytotoxic effect of honey bee venom and novel palladium complex against human T- cell acute lymphoblastic cell line (MOLT4) [abstract]. In Proceedings of FAOBMB Conference. Singapore; 2011.

23. Lariviere WR, Melzack R: The bee venom test: a new tonic-pain test. Pain 1996, 66(2-3):271-277.

24. Mansouri-Torshizi H, Eslami-Moghadam M, Divsalar A, Saboury AA: DNAbinding studies of some potential antitumor 2, 2'-bipyridine Pt (II)/Pd (II) complexes of piperidinedithiocarbamate. Their synthesis, spectroscopy and cytotoxicity. Acta Chim Slov 2011, 58:811-822.

25. Joza N, Susin SA, Daugas E, Stanford WL, Cho SK, Li CY, Sasaki T, Elia AJ, Cheng HY, Ravagnan L, Ferri KF, Zamzami N, Wakeham A, Hakem R, Yoshida H, Kong YY, Mak TW, Zuniga-Pflucker JC, Kroemer G, Penninger JM: Essential role of the mitochondrial apoptosisinducing factor in programmed cell death. Nature 2001, 410(6828):549-554

26. Li LY, Luo $X$, Wang $X$ : Endonuclease $G$ is an apoptotic DNase when released from mitochondria. Nature 2001, 412(6842):95-99.

27. Miramar MD, Costantini P, Ravagnan L, Saraiva LM, Haouzi D, Brothers G, Penninger JM, Peleato ML, Kroemer G, Susin SA: NADH oxidase activity 
of mitochondrial apoptosis-inducing factor. J Biol Chem 2001, 276(19):16391-16398.

28. Kroemer G, Martin SJ: Caspase-independent cell death. Nat Med 2005, 11(7):725-730.

29. Orsolic N: Potentiation of Bleomycin lethality in HeLa and V79 cells by bee venom. Arh Hig Rada Toksikol 2009, 60(3):317-326.

doi:10.1186/1678-9199-19-25

Cite this article as: Safaeinejad et al:: Potentiation of a novel palladium (II) complex lethality with bee venom on the human T-cell acute lymphoblastic leukemia cell line (MOLT-4). Journal of Venomous Animals and Toxins including Tropical Diseases 2013 19:25.

\section{Submit your next manuscript to BioMed Central and take full advantage of:}

- Convenient online submission

- Thorough peer review

- No space constraints or color figure charges

- Immediate publication on acceptance

- Inclusion in PubMed, CAS, Scopus and Google Scholar

- Research which is freely available for redistribution 